Final Technical Report: “Energy Saving Glass Lamination via Selective Radio Frequency Heating” Award No. DE-FG36-06GO16043, U.S. Department of Energy Inventions \& Innovations Program

\title{
Final Technical Report
}

Project Title: $\quad$ Energy Saving Glass Lamination via Selective Radio Frequency Heating

Award Number: Department of Energy DE-FG36-06G016043

Project Period: $\quad$ August 2006 through November 2009

Final Report Date: November 11, 2009

Recipient: $\quad$ Ceralink Inc

105 Jordan Road

Troy, NY 12180

Contact: P.I., Dr. Holly Shulman, Ceralink Inc. holly@ceralink.com Shawn Allan, Ceralink Inc. shawn@ceralink.com Patricia Strickland, Ceralink Inc. patricia@ceralink.com 518-283-7733 
Final Technical Report: "Energy Saving Glass Lamination via Selective Radio Frequency Heating” Award No. DE-FG36-06GO16043, U.S. Department of Energy Inventions \& Innovations Program

Acknowledgment: This report is based upon work supported by the U. S. Department of Energy under Award No. DE-FG36-06GO16043

Disclaimer: Any findings, opinions, and conclusions or recommendations expressed in this report are those of the author(s) and do not necessarily reflect the views of the Department of Energy

Proprietary Data Notice: No proprietary data is presented in this report.

Document Availability: Reports are available free via the U.S. Department of Energy (DOE) Information Bridge Website: http://www.osti.gov/bridge

Reports are available to DOE employees, DOE contractors, Energy Technology Data Exchange (ETDE) representatives, and Informational Nuclear Information System (INIS) representatives from the following source:

Office of Scientific and Technical Information

P.O. Box 62

Oak Ridge, TN 37831

Tel: (865) 576-8401

FAX: (865) 576-5728

E-mail: reports@osti.gov

Website: http://www.osti.gov/contract.html 
Final Technical Report: “Energy Saving Glass Lamination via Selective Radio Frequency Heating”

Award No. DE-FG36-06GO16043, U.S. Department of Energy Inventions \& Innovations Program

\section{Executive Summary}

This Inventions and Innovations program supported the technical and commercial research and development needed to elevate Ceralink's energy saving process for flat glass lamination from bench scale to a self-supporting technology with significant potential for growth. Radio-frequency heating was any un-explored option for laminating glass prior to this program. With significant commercial success through time and energy savings in the wood, paper, and plastics industries, RF heating was found to have significant promise for the energy intensive glass lamination industry.

A major technical goal of the program was to demonstrate RF lamination across a wide range of laminate sizes and materials. This was successfully accomplished, dispelling many skeptics' concerns about the abilities of the technology. Ceralink laminated panels up to 2' x 3', with four sets processed simultaneously, in a 3 minute cycle. All major categories of interlayer materials were found to work with RF lamination. In addition to laminating glass, other materials including photovoltaic silicon solar cells, light emitting diodes, metallized glass, plastics (acrylic and polycarbonate), and ceramics (alumina) were found compatible with the RF process. This opens up a wide range of commercial opportunities beyond the initially targeted automotive industry. The dramatic energy savings reported for RF lamination at the bench scale were found to be maintained through the scale up of the process. Even at 2' x 3' panel sizes, energy savings are estimated to be at least $90 \%$ compared to autoclaving or vacuum lamination.

With targeted promotion through conference presentations, press releases and internet presence, RF lamination has gained significant attention, drawing large audiences at American Ceramic Society meetings. The commercialization success of the project includes the establishment of a revenue-generating business model for providing process development and demonstrations for potential RF lamination users. A path to industrial energy benefits and revenue through industrial equipment sales was established in a partnership with Thermex Thermatron, a manufacturer of RF equipment. 
Final Technical Report: "Energy Saving Glass Lamination via Selective Radio Frequency Heating”

Award No. DE-FG36-06GO16043, U.S. Department of Energy Inventions \& Innovations Program

\section{Project Description}

1. Original project goals and objective: This program was formed to generate significant energy and cost savings in the glass industry through the development of RF heating systems and a process for laminating glass. Bench scale demonstrations of RF glass lamination were produced prior to this I\&I program. This I\&I project was intended to:

1) Develop a controlled process,

2) Develop the tools for laminating flat and curved glass in an RF Press, and

3) Develop a pilot system for production testing of glass laminates and other composite materials.

The program goals were to open new avenues for energy savings, cost reduction, increased efficiency, and decreased emissions, through the use of RF processing in the U.S. glass laminate and composites industries. This was to be accomplished by the creation of a revenue generating business at Ceralink to bring $\mathrm{RF}$ lamination to manufacturers through development projects, licensing, and equipment sales. A deliverable of the project was that a pilot system would be available for industry testing.

\section{Variance from original goals and objectives:}

Ceralink exceeded the original objectives and goals of the I\&I project. Ceralink demonstrated significant wide applicability of RF lamination to flat glass, plastic, and ceramic lamination in the automotive, architectural, photovoltaic, security, and transparent armor markets. Significant energy savings (>90\%) over traditional lamination methods were continually revalidated as laminate size increased and new materials were introduced.

Ceralink accomplished the objectives to:

1) Develop a controlled process

This was accomplished for laminating glass, acrylic, polycarbonate, silicon solar cells, ceramics, polyester films, cellulose acetate films, metallized glass and films, electric leads and wires, and light emitting diodes into glass, using over 20 types of interlayers from the three major categories - ethylene vinyl acetate (EVA), polyvinyl butyral (PVB), and thermoplastic polyurethane (TPU).

2) Develop tools for laminating glass in an RF press

Ceralink and Thermex Thermatron developed press platens and buffer systems to evenly distribute RF energy and mechanical pressure to glass panels up to 2' $\mathrm{x}$ 3'. Common vacuum bagging technologies were found to be compatible with RF lamination for products requiring vacuum. Currently used continuous prelamination systems involving heaters and nip-rollers are also fully compatible with the continuous nature of RF lamination. The tools developed for RF lamination can be incorporated into laboratory or production systems for use in specific applications. Rather than focus on 
Final Technical Report: "Energy Saving Glass Lamination via Selective Radio Frequency Heating”

Award No. DE-FG36-06GO16043, U.S. Department of Energy Inventions \& Innovations Program

Ceralink Inc.

November 11, 2009

curved glass platens, Ceralink modified the scope of work to target processes for successful lamination of large flat products, reaching into many markets beyond autoglass.

3) Develop a pilot system

Ceralink partnered with Thermex Thermatron to establish the ability to provide demonstration and even process development on a pilot RF press at Thermex Thermatron's laboratory. Materials from several companies were tested in the latter stages of the project, and further testing and demonstrations are continuing beyond the scope of the I\&I program. The I\&I program directly led to Ceralink's ability to receive a grant from New York State in 2009 to locate a lab-scale (18” x 20”) RF press on site at Ceralink, and to retrofit a much larger press at a nearby company, providing enhanced access to the technology for prospective users.

While the project objectives remained constant, several of the original project tasks were changed after receipt of the I\&I award. Ceralink's original industrial partner, PPG Industries, withdrew participation due to economic reasons. This led Ceralink to develop new tasks that greatly expanded Ceralink's understanding of the lamination market leading to significant contact with glass manufacturers, fabricators and laminators; the interlayer industry; solar manufacturers; transparent armor manufacturers; universities; and government agencies with vested interests in faster, cheaper, and greener lamination.

By the conclusion of the I\&I project, Ceralink had established RF lamination as an upand-coming technology, gaining significant attention from industry. Through Ceralink's publicity efforts, customer relationships were developed leading to the first private revenue generating business for Ceralink for RF lamination demonstration and development. In addition, Ceralink leveraged the I\&I project to win a $\$ 400,000$ award from New York State Energy Research and Development Authority, to ensure a continued commercialization effort through 2011.

\section{Discussion of work performed, hurdles overcome, findings, results and analysis}

Radio frequency (RF) Lamination has been developed as an alternative to conventional lamination processes, which are often considered bottlenecks in the fabrication of laminated products. Glass lamination - which covers diverse applications such as security "bullet resistant" glass, decorative architectural glass, furniture glass, solar panels, transparent armor, mirrors, and automotive windshields and side-lites - generally relies on slow, energy intensive autoclave or vacuum oven processes. Heat is required to melt the interlayers (e.g., vinyl or urethane) to allow bonding and transparency to occur in the laminate. However, heat must pass through the poorly conductive structural layers (e.g., glass, acrylic, polycarbonate, and/or ceramic), to reach the interlayers. These processes require anywhere from 30 minutes to 18 hours depending on the materials being laminated. 
Final Technical Report: "Energy Saving Glass Lamination via Selective Radio Frequency Heating” Award No. DE-FG36-06GO16043, U.S. Department of Energy Inventions \& Innovations Program

In RF Lamination, heat is transferred to the interlayers via radiowaves passed through the glass. Heating occurs through dielectric loss mechanisms, where materials with high dielectric loss (i.e., interlayers) produce more heat than materials with lower dielectric loss (i.e., structural layers). The lossy interlayers are heated directly and rapidly, allowing lamination to complete while maintaining lower temperatures in the glass, and at the outer surfaces of the laminates. When the RF heating is applied in an RF press (in which the press platens serve as the RF antennas or electrodes), sufficient temperature and pressure can be achieved in seconds, resulting in fully laminated glass products in cycles from 0.5 to 3 minutes.

\section{Phase I. Technology Development}

In this phase, Ceralink identified several materials and classes of laminated products for demonstration of RF lamination. Process parameters were developed experimentally for each materials set. The laminated materials were tested by various methods including environmental testing, optical transmission, and visual inspection. Photovoltaics and LEDs were also examined for proper functioning of the devices after lamination.

The challenges encountered in this phase included:

- Developing familiarity with laminated products, interlayers, and how the industry functions

- Limited access to materials - i.e., acquiring interlayer samples

- Overcoming skepticism about the ability of RF heating to laminate larger area panels, thick samples, and conductive materials (wires, solar cells, LEDs)

These challenges were overcome through persistence in researching applications, current lamination methods, interlayer manufacturers, and through experimentation (metallized glass, solar cells, LEDs, multilayers) using an objective technical approach.

Task 1 covered materials selection. Table I lists the structural materials, and Table II lists the interlayers demonstrated in this project. Several combinations of these materials were also tested, such as glass-to-ceramic, glass-to-plastic, acrylic-to-polycarbonate, and glass to silicon solar cells. The sizes of materials listed show what was demonstrated, but do not imply any limitation to the process. 
Final Technical Report: "Energy Saving Glass Lamination via Selective Radio Frequency Heating” Award No. DE-FG36-06GO16043, U.S. Department of Energy Inventions \& Innovations Program

Table I. List of the structural materials demonstrated with RF Lamination in this project.

\begin{tabular}{|c|}
\hline Structural Materials \\
Glass \\
(up to 1/2” thick) \\
\hline Metallized glass \\
$\begin{array}{c}\text { Acrylic } \\
\text { (up to 1” thick) }\end{array}$ \\
\hline $\begin{array}{c}\text { Polycarbonate } \\
\text { (up to 1” thick) }\end{array}$ \\
\hline Single crystal silicon solar cells \\
\hline Polycrystalline silicon solar cells \\
\hline Wires (e.g., for solar cells) \\
\hline Printed polyester (PET) films \\
\hline Printed cellulose acetate films \\
\hline Alumina (ceramic) \\
\hline PET films containing light emitting diodes \\
(LEDs) \\
\hline $\begin{array}{c}\text { Multilayer structures } \\
\text { 5 layers of mixed glass, acrylic, polycarbonate } \\
\text { bonded with up to 4 sheets of interlayer }\end{array}$ \\
\hline
\end{tabular}

Table II. List of the interlayers demonstrated with RF Lamination in this project.

\begin{tabular}{|c|}
\hline Interlayers \\
\hline DuPont PVB \\
\hline $\begin{array}{c}\text { DuPont Sentryglas Expressions printed } \\
\text { PVB }\end{array}$ \\
\hline Sekisui PVB \\
\hline Solutia PVB (2 grades) \\
\hline Sekisui S-LEC EN, EVA film \\
\hline Bridgestone EVASAFE EVA film \\
\hline $\begin{array}{l}\text { Nanjing Kin Yong Fa EVA } \\
15 \text { grades including: } \\
\text { 0.015” clear, 0.030" clear, 0.045” clear, } \\
\text { light blue, dark blue, opaque blue, yellow, } \\
\text { red, pink, orange, light green, dark green, } \\
\text { purple, brown, opaque green, opaque white }\end{array}$ \\
\hline Deerfield A4700 TPU \\
\hline Huntsman TPU \\
\hline
\end{tabular}

The successful RF Lamination of light emitting diodes was especially interesting given the tendency for LEDs to degrade in high voltage fields. RF Lamination is a voltage driven process and therefore the ability to laminate LEDs was uncertain. Testing via the lamination of LED-bearing PET films quickly proved that LEDs could be successfully laminated using RF Lamination (Figure 1). 
Final Technical Report: "Energy Saving Glass Lamination via Selective Radio Frequency Heating” Award No. DE-FG36-06GO16043, U.S. Department of Energy Inventions \& Innovations Program
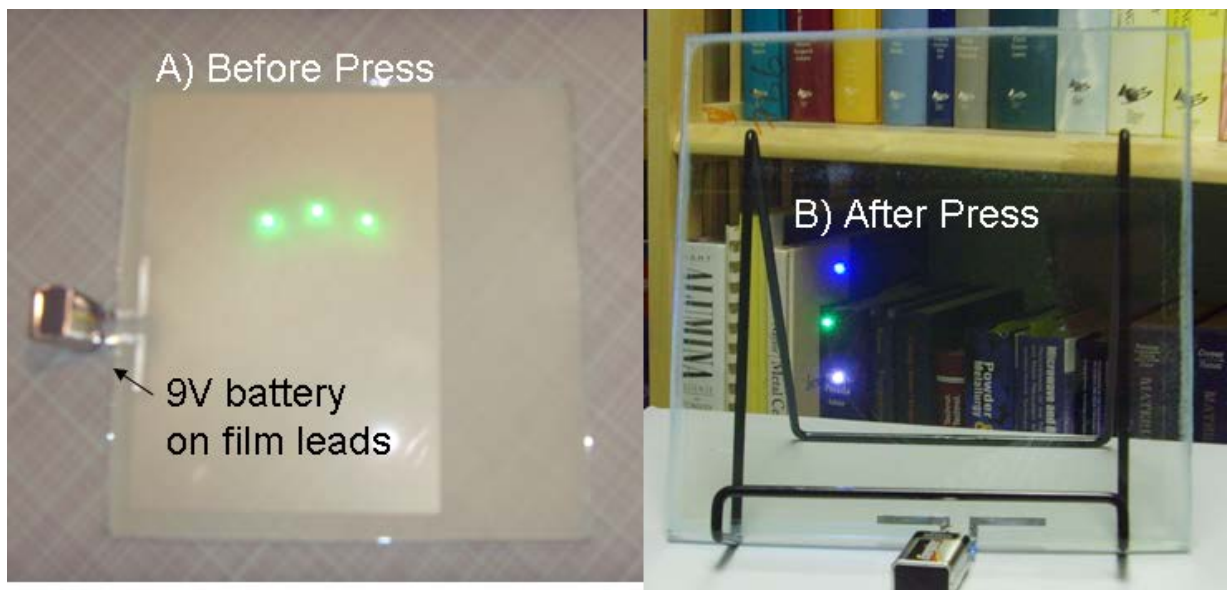

Figure 1. Polyester (PET) films with embedded light emitting diodes (LEDs) were laminated into glass using polyvinyl butyral (PVB) interlayers. A) three lit LEDs and the silhouette of the PET film can be seen assembled within the glass before lamination. B) after lamination, the PET film and PVB are invisible, while the LEDs shine from within the laminate

Solar cell lamination was a significant interest, as the majority of solar panels are laminated into glass or plastics, to protect the delicate photovoltaic materials from damage. The RF Laminated solar panels converted sunlight to electricity as expected (Figure 2). Ceralink found that solar panel lamination using the RF process elminated the need for soldering. The solar cell leads, typically a ribbon wire, were placed directly between the solar cell and interlayer. The RF press, ensured reliable electrical contact between the solar cells and external leads in the solar panels. The implications of eliminating solder (i.e., solders containing lead) from solar cell manufacturing is a significant environmental advantage that will support RoHS compliance in solar panel manufacture.
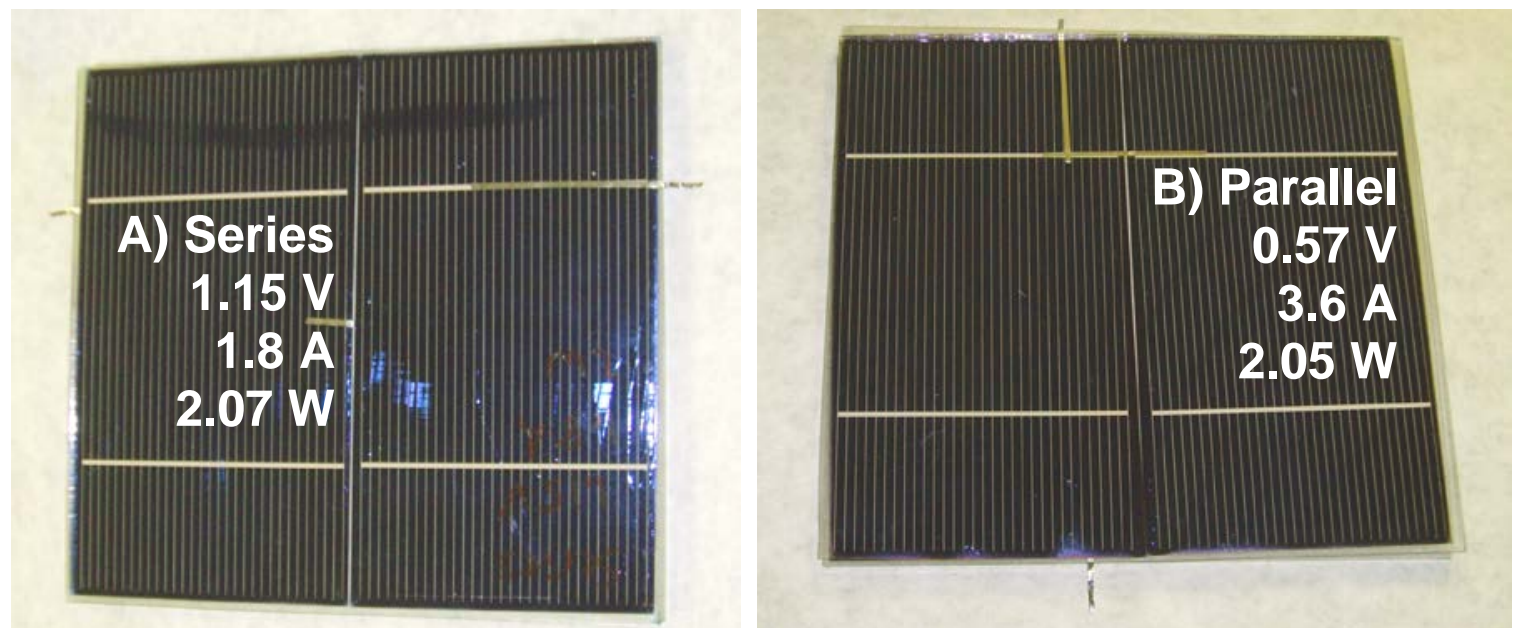

Figure 2. Dual-cell solar panels, 6" x 6.5”, laminated in (A) series, and (B) parallel with solderless RF lamination in a 45 second process. The solar panels produce equivalent power, with variation in current and voltage depending on the wiring of the cells. 
Final Technical Report: "Energy Saving Glass Lamination via Selective Radio Frequency Heating”

Award No. DE-FG36-06GO16043, U.S. Department of Energy Inventions \& Innovations Program

Ceralink Inc.

November 11, 2009

\section{Laminate Testing}

Laminates were tested throughout the project by visual inspection, and in some cases with accelerated environmental testing, and electronic performance.

Accelerated environmental testing of EVA, PVB, and TPU interlayer RF laminates was conducted. TPU was tested using a standard boil-test in $100{ }^{\circ} \mathrm{C}$ water for 2 hours. The boil test of a clear, defect free RF laminated TPU sample resulted in a positive result. No bubbles were formed, nor did edge delamination or haze occur (Figure 3). Several EVA laminates were tested in the same manner and produced equally positive results.
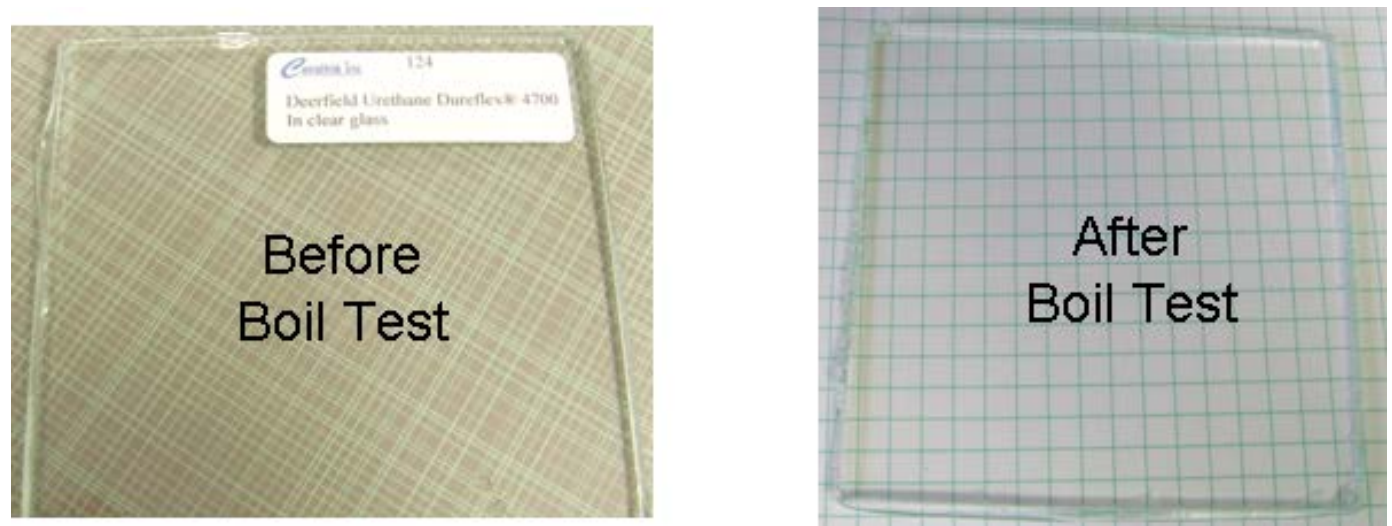

Figure 3. Before and after photographs of 1.5 year room-temperature aged thermoplastic polyurethane (TPU) RF-laminated sample, subjected to boil test -2 hours in boiling water. The sample passed the test, retaining defect free clarity after boiling, with no development of bubbles, delamination, or haze.

Bake testing (a dry heating test) of clear, defect free PVB samples (one newly laminated, and two aged samples of different PVBs), revealed dissolved air or moisture in the laminates. The air was manifested as bubbles after being heated to $\sim 100{ }^{\circ} \mathrm{C}$ for 1 hour, see Figure 4. The bubbling indicated that the PVB absorbed moisture from the air in storage prior to lamination. PVB is well known to absorb moisture from the air if not properly stored, resulting in bubbling during environmental heat tests. This issue should be eliminated by performing the RF Lamination of PVB in an environmentally controlled site, such as at a glass manufacturer's facility.

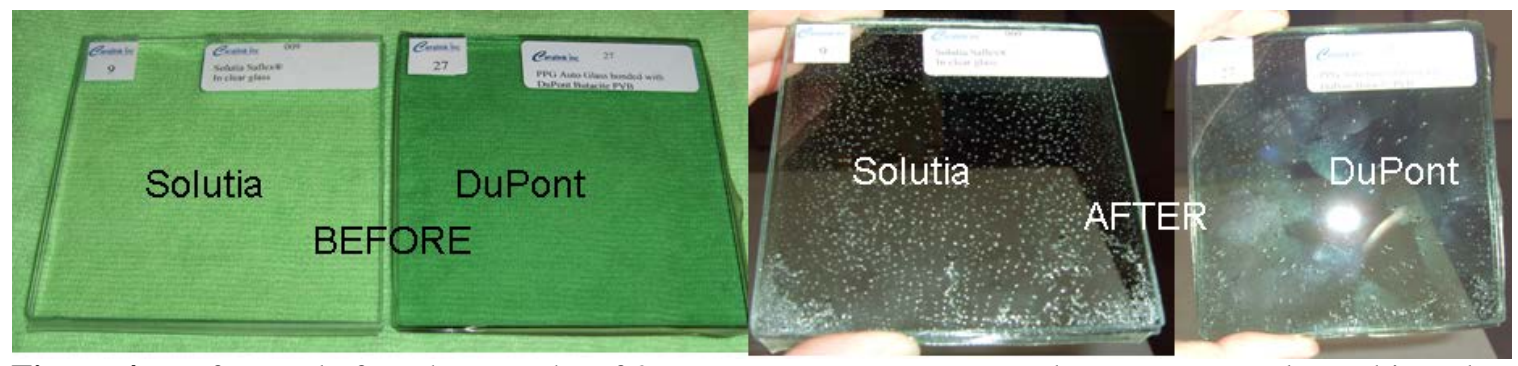

Figure 4. Before and after photographs of 2 year room-temperature aged PVB test samples, subjected to bake test at $\sim 110{ }^{\circ} \mathrm{C}$ for 1 hour. The laminates appeared clear and defect free before the bake test and exhibited no delamination in the 2 years since lamination. After a 1 hour bake test, the samples developed numerous bubbles indicative of dissolved air. No hazing or delamination was observed, indicating otherwise strong adhesion to the glass. 
Final Technical Report: "Energy Saving Glass Lamination via Selective Radio Frequency Heating” Award No. DE-FG36-06GO16043, U.S. Department of Energy Inventions \& Innovations Program

\section{Phase II. Platen Design and Building}

The challenge of Phase 2 was to develop process tools to enable lamination of a variety of products, with increasing size. Ceralink targeted press platens and a buffering system to accomplish this task. Laminated pieces up to 16 " x 18 " were successfully produced in November 2008, using an existing RF Press at Thermex Thermatron. This achievement resulted from the development of platens and buffering suitable for glass lamination. The specific technical details of the resulting platen and buffer layer design are considered confidential were therefore excluded from this report. Reproducible lamination of 1 and $2 \mathrm{ft}^{2}$ panels represents a successful outcome for Phase II. These outcomes prepared Ceralink for the significant progress achieved in Phase III, described below.

\section{Phase III. Pilot System Demonstration}

Phase III involved transitioning the RF lamination process to a larger press at Thermex Thermatron. Thermex brought a large, 30" x 40" RF press online for the glass lamination testing. This press served as a pilot demonstration site, where Ceralink and Thermex can perform demonstration and development work for prospective users of the technology. Ceralink and Thermex established an agreement for joint promotion of the technology and sales of equipment.

\section{Maximizing Area}

With further refinement of buffer system developed in Phase II, Ceralink and Thermex made major advances in 2009, that facilitated lamination of $\mathbf{6} \mathbf{f t}^{2}$ (24” x 36”) panels. This work achieved a major goal of the project by demonstrating large scale flat glass lamination. The experiments indicated that press size was the only limiting factor for demonstration of scale. Even at $6 \mathrm{ft}^{2}$, the $30 \mathrm{~kW}$ RF generator was not operating near full power. The pressure required for the $6 \mathrm{ft}^{2}$ panels was less than half the maximum available on the press (only 19 of 60 tons), indicating excellent scalability potential. A 6 $\mathrm{ft}^{2}$ panel is shown in Figure 5, along with panels of each size tested during the course of this project, down to the original bench scale of just 4" x 4". The progress achieved represented a 54-fold increase in laminated area. 


\section{Demonstrated sizes}

\begin{tabular}{|c|c|}
\hline $36 ” \times 24 ”$ & $6 \mathrm{ft}^{2}$ \\
\hline 24” x 24” & $4 \mathrm{ft}^{2}$ \\
\hline 18" x 16" & $2 \mathrm{ft}^{2}$ \\
\hline 12" x 12" & $1 \mathrm{ft}^{2}$ \\
\hline 9" x 9" & $0.56 \mathrm{ft}^{2}$ \\
\hline 6" x 6" & $0.25 \mathrm{ft}^{2}$ \\
\hline $4 " \times$ 4" & $0.11 \mathrm{ft}^{2}$ \\
\hline
\end{tabular}

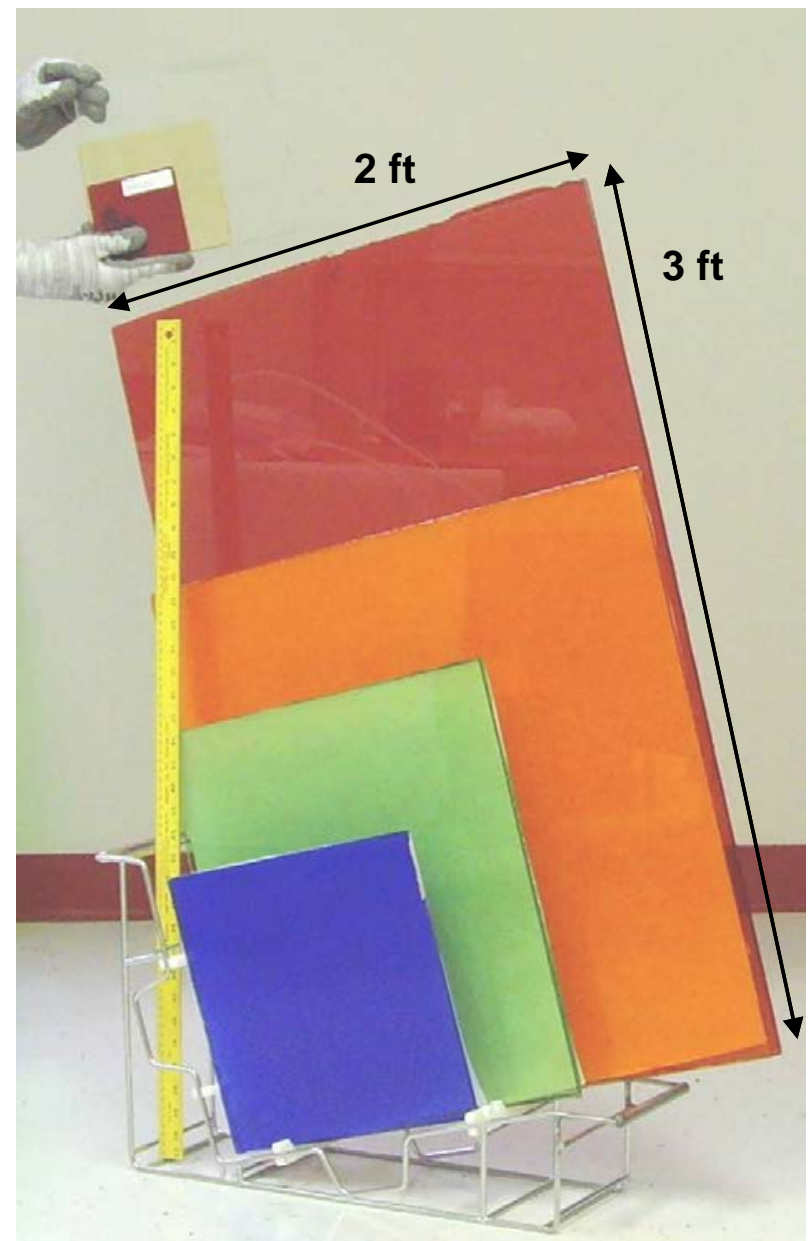

Figure 5. Demonstration of the sizes of glass panels laminated using RF Lamination

\section{Increasing Throughput}

In an extremely important result, up to 4 stacked panels (with EVA interlayer) were laminated simultaneously, for a throughput of at least $24 \mathrm{ft}^{2}$ per cycle with the pilot system. Most intriguingly, the cycle time for laminating one panel or four, did not change - requiring just 3 minutes in either case (Figures 6, 7, and 8). This differs drastically from a conventional heating scenario, where heat must travel through the laminates via thermal conduction. The time required to conventionally heat thick stacks of material is proportionally longer than heating thin materials. These experiments proved that the direct delivery of RF energy to the interlayers eliminated the dependence of heating on thermal conduction. Laminate size did not significantly effect lamination time for stacked laminates (e.g., 2' x 2' vs. 2' x 3'). Stacking resulted in a total per-cycle laminated area 216 times larger than the original bench scale 4" x 4" samples. 
Final Technical Report: "Energy Saving Glass Lamination via Selective Radio Frequency Heating” Award No. DE-FG36-06GO16043, U.S. Department of Energy Inventions \& Innovations Program

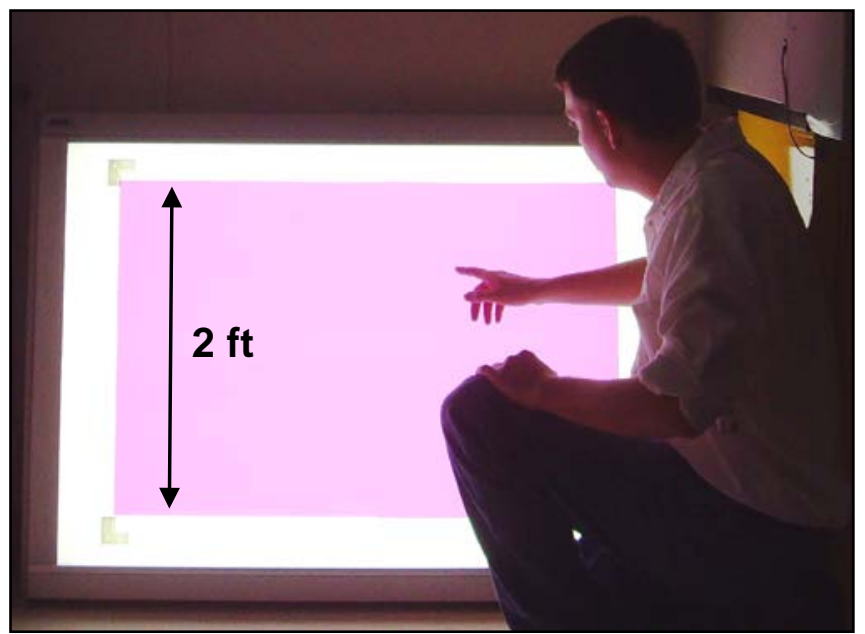

Figure 6. Photograph of a single laminated panel, 2' $x$ 3', requiring 3 minutes to laminate.
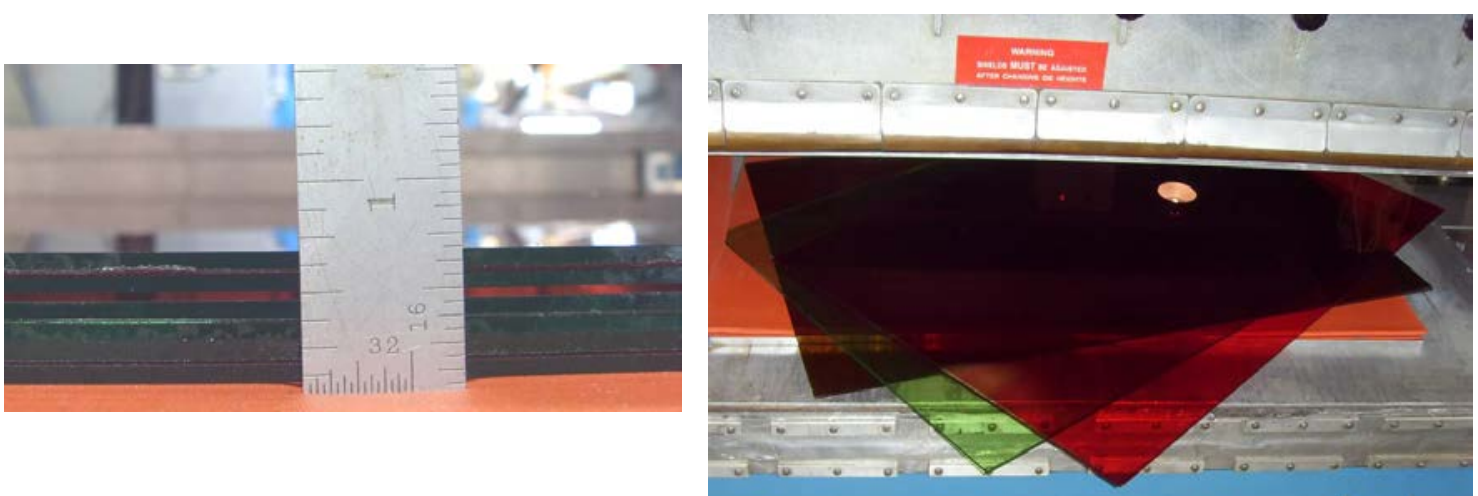

Figure 7. Photographs of a $~ 5 / 8$ ” thick RF laminated stack of 3 panels, 2' $x$ 3' each, processed in 3 minutes.

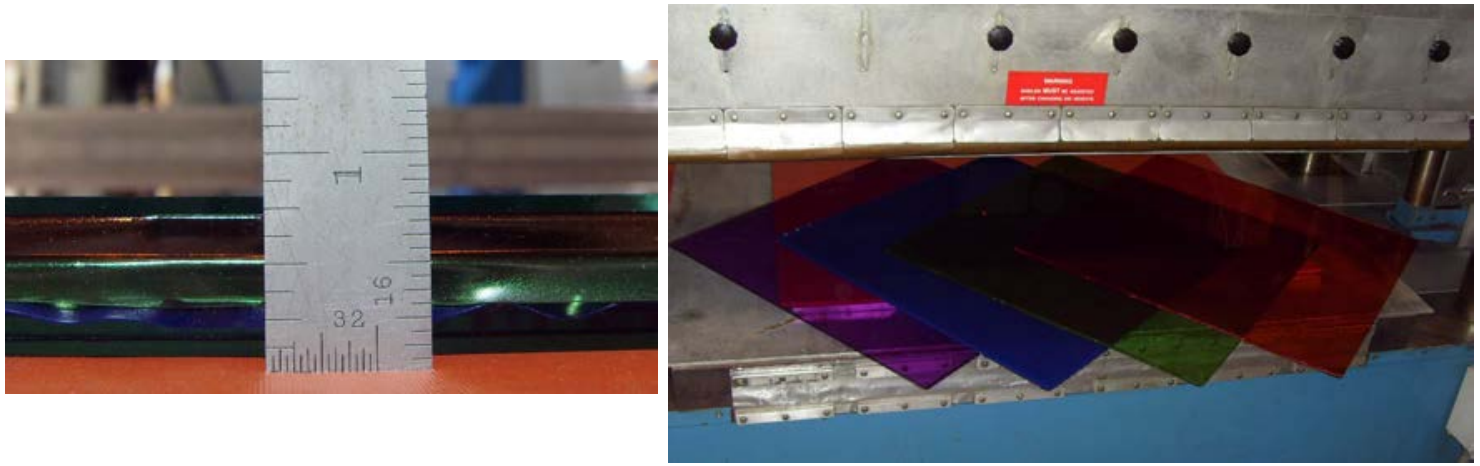

Figure 8. Photographs of an over $3 / 4$ ”' thick RF laminated stack of 4 panels, 2' x 2' each, processed in 3 minutes.

Figure 9 shows a plot of lamination time based upon throughput. The regimes of the graph indicating throughput based on individual panel size, and throughput based on combined area via stacking is indicated. Note that with stacking, significant throughput 
Final Technical Report: "Energy Saving Glass Lamination via Selective Radio Frequency Heating” Award No. DE-FG36-06GO16043, U.S. Department of Energy Inventions \& Innovations Program

gains were achieved without increasing the time required to laminate. This indicated that the transfer of heat to the interlayers was not time dependent, and therefore, as expected, was not dependent on thermal conductivity.

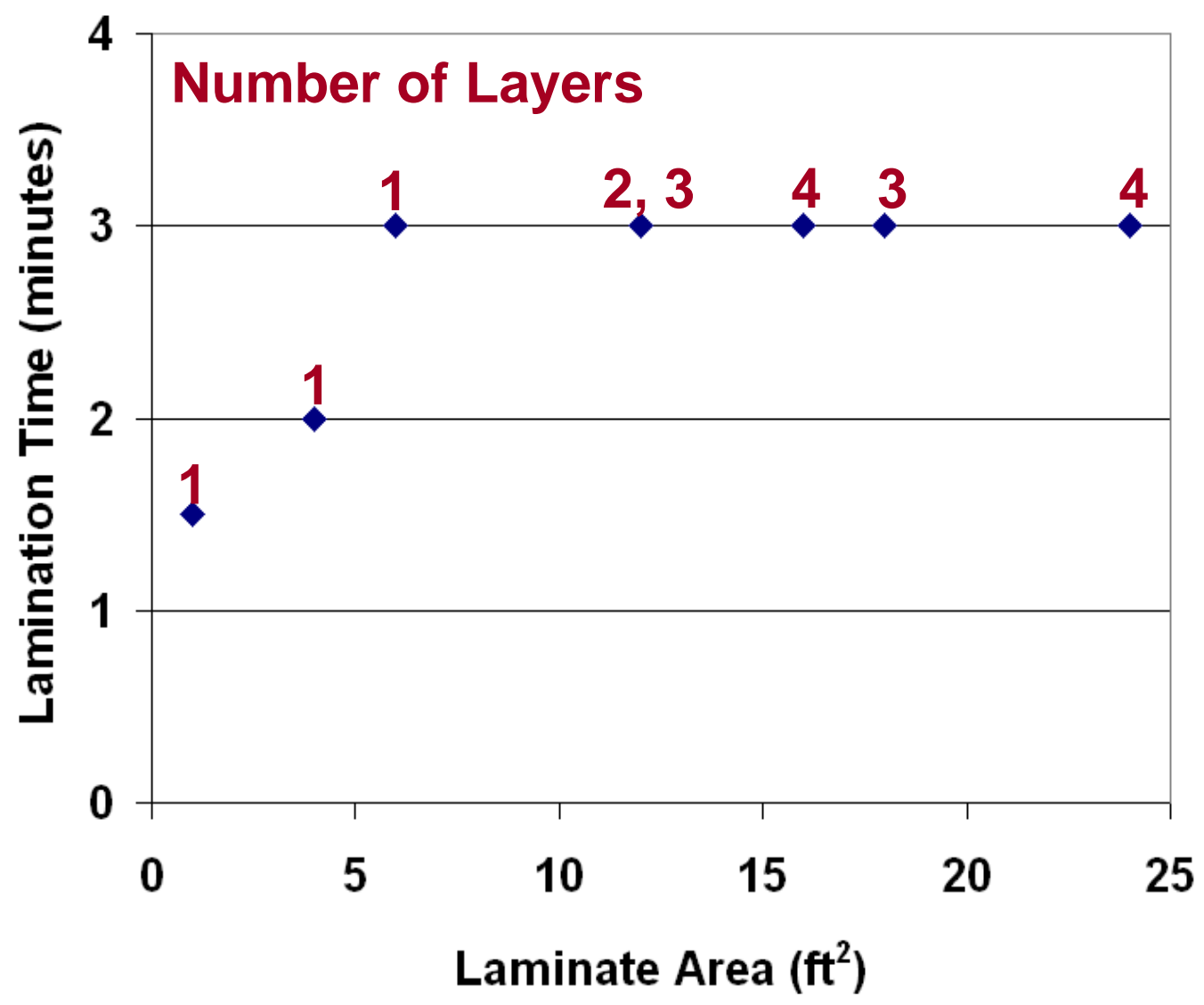

Figure 9. Plot of RF lamination time vs. laminated area.

\section{Lamination Energy Consumption}

In the original bench scale work, the energy savings over autoclaving was determined to exceed 95\%. An important determination in this project was to find if the energy savings would persist as the process was scaled up. Throughout the course of the project, more accurate autoclave and vacuum lamination energy consumption data was obtained. Also, energy consumption data for the RF process was generated for several individual and stacked laminate areas. For the RF Lamination examples shown in Figures 7 and 8, values for energy consumption per $1,000 \mathrm{ft}^{2}$ were determined to be 40.5 and $47.5 \mathrm{kWh}$ respectively. This compared with an estimated range for vacuum or autoclave processing of 1,150 to $4,000 \mathrm{kWH}$ per $1,000 \mathrm{ft}^{2}$. This indicated a minimum energy savings of $96 \%$, with per cycle lamination as large as $24 \mathrm{ft}^{2}$.

By stacking panels, the increase of lamination energy from $6 \mathrm{ft}^{2}$ to $24 \mathrm{ft}^{2}$ (400\% area increase) was only 47\% (Figure 10). The energy data through Phases I, II, and III allows Ceralink and Thermex Thermatron to estimate power requirements for larger systems, and predict how energy consumption will scale for various processes. This has 
Final Technical Report: "Energy Saving Glass Lamination via Selective Radio Frequency Heating” Award No. DE-FG36-06GO16043, U.S. Department of Energy Inventions \& Innovations Program

significant implications on the capital equipment and operational cost, payback time period, and return on investment for manufacturers that uptake RF Lamination.

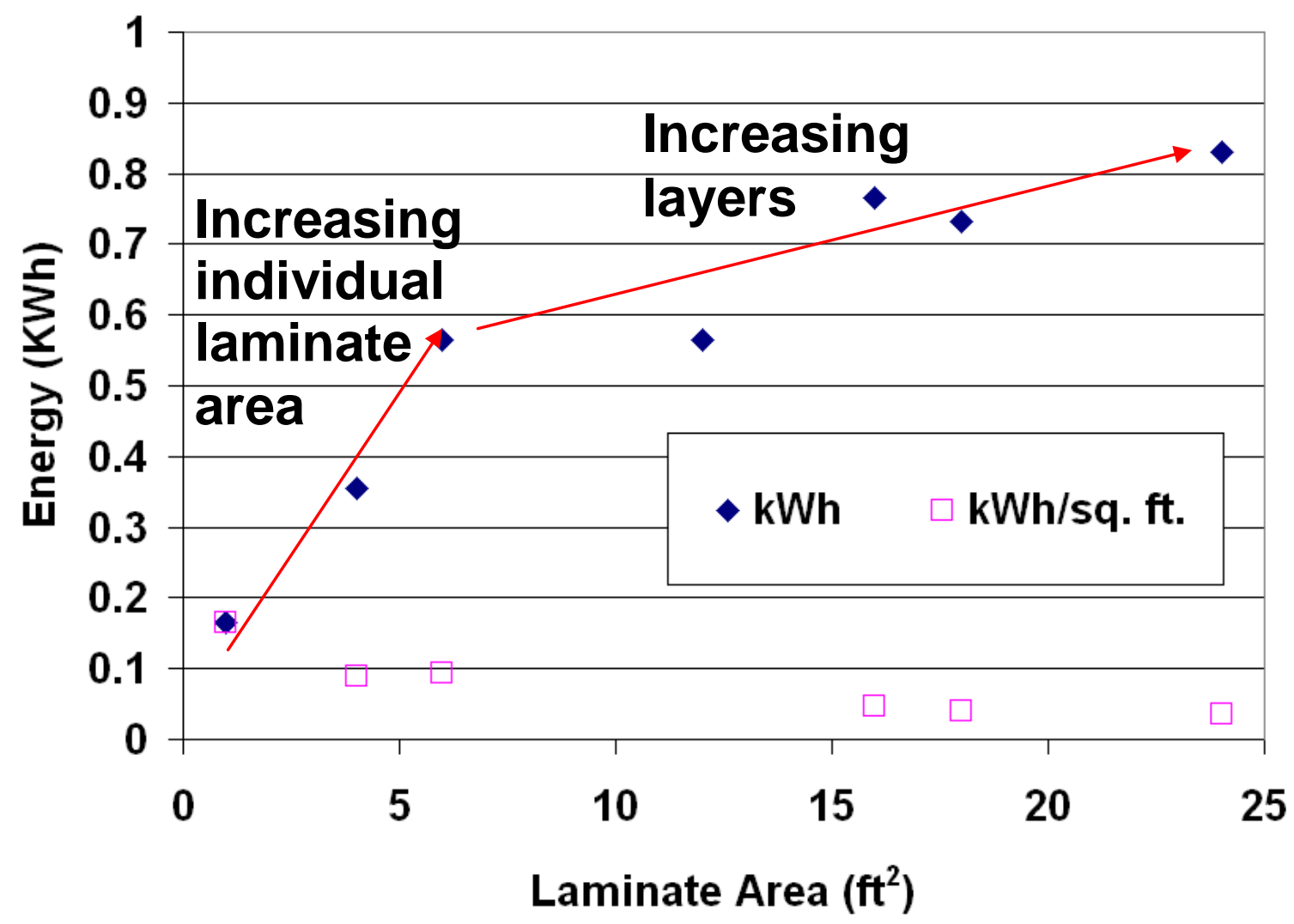

Figure 10. Graph of lamination energy vs. laminate area. The efficiency generally improves as laminate are increases, with less energy required per square foot. Stacking laminates was found to be highly energy efficient.

\section{RF Press systems}

Ceralink used two Thermex Thermatron RF presses for the work performed in this project. The initial development work was performed in a lab-scale 18” x 20", $10 \mathrm{~kW}$ RF press shown in Figure 11A. The pilot scale, 30" x 40", $30 \mathrm{~kW}$ press used in Phase III is shown in Figure 11B. As mentioned previously, RF press technology has been commercialized in other industries, and much larger systems have been built. Figure 11C shows an example of a 4' x 10' RF press built by Thermex for a different process. The infrastructure exists to rapidly scale RF Lamination for customer requirements. 


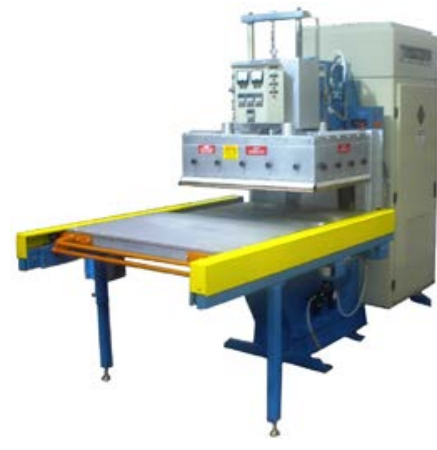

A. 4 ton, 18” $\times 20 ”$
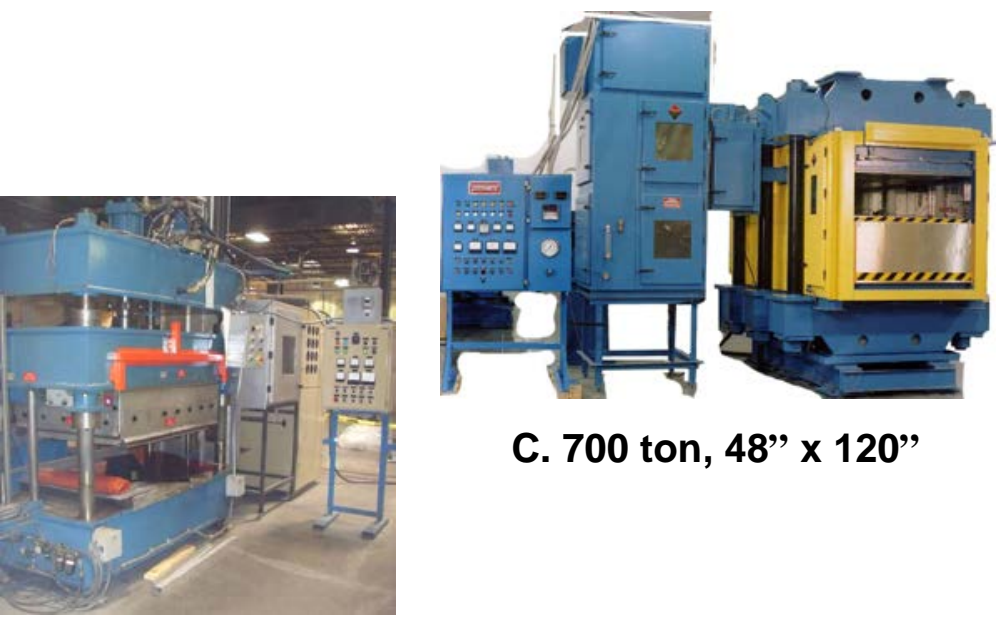

C. 700 ton, $48 ” \times 120 ”$

B. 19 ton, $30 ” \times 40 ”$

Figure 11. Photographs of RF presses suitable for RF Lamination. A) lab-scale press used in Phases I \& II work. B) pilot press used in Phases II \& III work, C) large press sold by Thermex Thermatron for another application, demonstrating the existing scalability of the RF press technology.

\section{Phase IV. Marketing and Commercialization Strategy}

Through the I\&I program, Ceralink explored marketing and commercialization through three primary avenues:

1) IP protection - Ceralink filed a U.S. Patent for the RF Lamination technology. As of this final report, the application is still pending.

2) Marketing to potential clients

- Devoted web resources to RF Lamination at www.ceralink.com

0 press releases and presentations on RF Lamination on website

- Branded the technology as "FastFuse ${ }^{\mathrm{TM}}$ " including the logo:

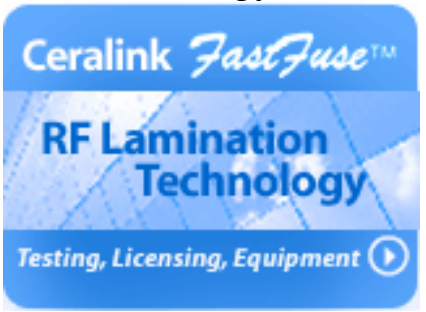

- $\quad$ Presented 7 presentations at 6 conferences, including 2 invited presentations

- Presented at 10 technology fairs and tradeshow expositions in a joint booth with RF equipment manufacturer, Thermex Thermatron

- Published 7 press releases, including a "new product" announcement in U.S. Glass magazine. 
Final Technical Report: "Energy Saving Glass Lamination via Selective Radio Frequency Heating” Award No. DE-FG36-06GO16043, U.S. Department of Energy Inventions \& Innovations Program

- Achieved first commercial projects for RF Lamination prior to Final Report

In addition, Ceralink leveraged the technical and marketing gains made in the I\&I project to successfully compete for funding from New York State to continue RF Lamination commercialization and development well into 2011. Ceralink's new NYSERDA project provides funding to place an RF press at Ceralink's location in Troy, NY. This will facilitate Ceralink's demonstration of RF lamination to customers. This press, for which design is currently being considered, will be the first $R F$ Press built exclusively for FastFuse $^{\mathrm{TM}}$ RF Glass Lamination. Ceralink will promote this major advance when the RF Press is delivered.

\section{Conclusions and recommendations for future work}

The Department of Energy I\&I support for RF Lamination has allowed this innovative, tremendously energy saving method for glass lamination to cross from initial feasibility to commercial viability. The wide range of sizes, thicknesses, and materials demonstrated, as well as the persistently impressive process times and energy savings, contributed to the success of this program. Ceralink's conference, trade magazine, internet, and direct calling approach to marketing has garnered significant attention including 13 technology support letters and nearly $\$ 300,000$ cost share for ongoing efforts to continue commercialization and development.

Future work plans for RF Lamination include:

- installation of a lab-scale press at Ceralink for demonstrations and process development

- retrofitting of a larger press at a photovoltaics company near Ceralink in New York

- continued industry supported projects at Ceralink and Thermex Thermatron

- continued collaboration with Thermex Thermatron for joint promotion and sales of RF Lamination

- development of stand alone website, www.fastfuse.net for RF Lamination 
Final Technical Report: "Energy Saving Glass Lamination via Selective Radio Frequency Heating”

Award No. DE-FG36-06GO16043, U.S. Department of Energy Inventions \& Innovations Program

Ceralink Inc.

November 11, 2009

\section{Appendix A}

\section{Final Task Schedule}

\begin{tabular}{|c|c|c|c|c|c|c|}
\hline \multicolumn{7}{|c|}{ Task Schedule } \\
\hline \multirow{2}{*}{$\begin{array}{l}\text { Task } \\
\text { Number }\end{array}$} & \multirow{2}{*}{$\begin{array}{l}\text { Task } \\
\text { Description }\end{array}$} & \multicolumn{4}{|c|}{ Task Completion Date } & \multirow[b]{2}{*}{ Progress Notes } \\
\hline & & $\begin{array}{l}\text { Original } \\
\text { Planned }^{* 1}\end{array}$ & $\begin{array}{l}\text { Revised } \\
\text { Date }\end{array}$ & Actual & $\begin{array}{l}\text { Percent } \\
\text { Complete }\end{array}$ & \\
\hline 1 & $\begin{array}{l}\text { Materials } \\
\text { Selection }\end{array}$ & $11 / 13 / 06$ & $8 / 1 / 07$ & 11/30/08 & $100 \%$ & $\begin{array}{l}\text { Task is complete. More } \\
\text { samples may be obtained } \\
\text { if relevant }\end{array}$ \\
\hline 2 & $\begin{array}{l}\text { Bench Scale } \\
\text { Trials with } \\
\text { Designed } \\
\text { Experiments }\end{array}$ & $2 / 13 / 07$ & 9/13/07 & 11/30/08 & $100 \%$ & $\begin{array}{l}6 \text { glass types, over } 20 \\
\text { interlayers, over } 200 \\
\text { experiments on } 4 \text { " and 6” } \\
\text { test squares. Solar, } \\
\text { multilayer \& multisample }\end{array}$ \\
\hline 3 & $\begin{array}{l}\text { Testing and } \\
\text { Evaluation of } \\
\text { DOE }\end{array}$ & $4 / 18 / 07$ & $12 / 31 / 08$ & $11 / 30 / 08$ & $100 \%$ & $\begin{array}{l}\text { Visual inspections ASTM } \\
\text { E1172, EN/ISO boil and } \\
\text { bake tests completed. }\end{array}$ \\
\hline 4 & Equip. Design & $4 / 16 / 07$ & $10 / 30 / 08$ & 11/30/08 & $100 \%$ & $\begin{array}{l}\text { Parallel fixture designed } \\
\text { and reworked }\end{array}$ \\
\hline 5 & $\begin{array}{l}\text { Platen } \\
\text { Construction }\end{array}$ & 6/15/07 & $10 / 30 / 08$ & $11 / 30 / 08$ & $100 \%$ & $\begin{array}{l}\text { Parallel fixtures built. } \\
\text { Buffers explored. }\end{array}$ \\
\hline 6 & Pressing Trials & 9/12/07 & $12 / 30 / 08$ & $11 / 30 / 08$ & $100 \%$ & $2 \mathrm{ft}^{2}$ lamination successful \\
\hline 7 & $\begin{array}{l}\text { Testing of } \\
\text { Laminates }\end{array}$ & 9/27/07 & $12 / 30 / 08$ & $11 / 30 / 08$ & $100 \%$ & $\begin{array}{l}\text { Visual inspection of } \\
\text { samples, ASTM E1172 }\end{array}$ \\
\hline 8 & $\begin{array}{l}\text { Design of Pilot } \\
\text { System }\end{array}$ & $10 / 12 / 07$ & 6/30/09 & 6/30/09 & $100 \%$ & 8 sq ft. press operational \\
\hline 9 & $\begin{array}{l}\text { Construction of } \\
\text { Pilot System }\end{array}$ & 2/12/08 & 8/14/09 & 6/30/09 & $100 \%$ & $\begin{array}{l}\text { Larger platens will be } \\
\text { built }\end{array}$ \\
\hline 10 & $\begin{array}{l}\text { Pilot System } \\
\text { Proving }\end{array}$ & $4 / 15 / 08$ & 8/14/09 & 6/30/09 & $100 \%$ & $\begin{array}{l}\text { Acquired commercial } \\
\text { samples for pilot } \\
\text { demonstration }\end{array}$ \\
\hline 11 & $\begin{array}{l}\text { Pilot } \\
\text { Production }\end{array}$ & 8/14/08 & 8/14/09 & 6/30/09 & $100 \%$ & $\begin{array}{l}\text { First commercial } \\
\text { demonstrations scheduled }\end{array}$ \\
\hline $12 \mathrm{a}$ & Marketing & 8/14/08 & 8/14/09 & $8 / 14 / 09$ & $100 \%$ & $\begin{array}{l}\text { Major success at Daytona } \\
\text { conference. }\end{array}$ \\
\hline $12 b$ & $\begin{array}{l}\text { Foster Industry } \\
\text { Participation }\end{array}$ & 8/14/08 & 8/14/09 & 8/14/09 & $100 \%$ & $\begin{array}{l}\text { Several support letters, } \\
\text { industrial samples }\end{array}$ \\
\hline 13 & IP Protection & 8/14/08 & 8/14/09 & 8/14/09 & $100 \%$ & $\begin{array}{l}\text { Patent app. in } \\
\text { Examination stage at PTO }\end{array}$ \\
\hline 14 & $\begin{array}{l}\text { Expand } \\
\text { Consortium } \\
\text { Uptake }\end{array}$ & 8/14/08 & N/A & & N/A & $\begin{array}{l}\text { Consortium idea } \\
\text { dismissed }\end{array}$ \\
\hline 15 & $\begin{array}{l}\text { Project } \\
\text { Management }\end{array}$ & 8/14/08 & 8/14/09 & 8/14/09 & $100 \%$ & $\begin{array}{l}\text { On-time reporting, } \\
\text { payment system set up. }\end{array}$ \\
\hline
\end{tabular}

${ }^{1}$ The project kick-off was September 14, 2006. 
Final Technical Report: "Energy Saving Glass Lamination via Selective Radio Frequency Heating” Award No. DE-FG36-06GO16043, U.S. Department of Energy Inventions \& Innovations Program

\section{Appendix B}

\section{Final Spending Schedule}

\begin{tabular}{|c|c|c|c|}
\hline \multirow{2}{*}{\multicolumn{2}{|c|}{ Spending Schedule }} & Project Period: & $\begin{array}{l}08 / 15 / 06 \text { to } 8 / 14 / 08 \\
\text { Extended to } 08 / 14 / 09 \\
\end{array}$ \\
\hline & & Current Quarter: & $04 / 01 / 09$ to $06 / 30 / 09$ \\
\hline \multirow{2}{*}{ Task } & \multirow{2}{*}{ Approved Budget } & \multicolumn{2}{|l|}{ Project Expenditures } \\
\hline & & This Quarter & Cumulative to Date \\
\hline 1. Materials Selection & 12,239 & & 13,379 \\
\hline $\begin{array}{l}\text { 2. Bench Scale Trials } \\
\text { with Designed } \\
\text { Experiments }\end{array}$ & 46,000 & & 40,873 \\
\hline $\begin{array}{l}\text { 3. Testing and } \\
\text { Evaluation of DOE }\end{array}$ & 11,000 & & 20,653 \\
\hline 4. Equipment Design & 34,000 & & 17,812 \\
\hline 5. Platen Construction & 41,000 & & 23,220 \\
\hline 6. Pressing Trials & 54,000 & & 42,837 \\
\hline 7. Testing of Laminates & 12,000 & & 9,839 \\
\hline $\begin{array}{l}\text { 8. Design of Pilot } \\
\text { System }\end{array}$ & 40,000 & & 15,086 \\
\hline $\begin{array}{l}\text { 9. Construction of Pilot } \\
\text { System }\end{array}$ & 41,000 & & 13,661 \\
\hline $\begin{array}{l}\text { 10. Pilot System } \\
\text { Proving }\end{array}$ & 15,748 & & 11,577 \\
\hline 11. Pilot Production & 39,000 & & 9,177 \\
\hline 12a. Marketing & 25,000 & & 68,244 \\
\hline $\begin{array}{l}\text { 12b. Foster Industry } \\
\text { Participation }\end{array}$ & 20,000 & & 22,871 \\
\hline 13. IP Protection & 0 & & 31,145 \\
\hline $\begin{array}{l}\text { 14. Expand Consortium } \\
\text { Uptake }\end{array}$ & 0 & & 0 \\
\hline 15. Project Management & & & 32,119 \\
\hline Total & 390,987 & $\mathbf{0}$ & 372,495 \\
\hline DOE Share & 249,287 & 0 & 249,289 \\
\hline Cost Share & 101,700 & 0 & 123,206 \\
\hline
\end{tabular}


Final Technical Report: "Energy Saving Glass Lamination via Selective Radio Frequency Heating” Award No. DE-FG36-06GO16043, U.S. Department of Energy Inventions \& Innovations Program

\section{Appendix C}

Final Cost Share Contributions

\section{Cost Share Contributions}

\begin{tabular}{|c|c|c|c|c|c|c|}
\hline \multirow{2}{*}{ Funding Source } & \multicolumn{2}{|c|}{ Approved Cost Share } & \multicolumn{2}{|l|}{ This Quarter } & \multicolumn{2}{|c|}{ Cumulative to Date } \\
\hline & Cash & In-Kind & Cash & In-Kind & Cash & In-Kind \\
\hline Ceralink Inc & 61,700 & & & & 83,931 & \\
\hline $\begin{array}{l}\text { Thermex } \\
\text { Thermatron }\end{array}$ & & 40,000 & & & & 30,000 \\
\hline $\begin{array}{l}\text { Other } \\
\text { Participants }\end{array}$ & & & & & & 9,275 \\
\hline Total & 61,700 & 40,000 & $\mathbf{0}$ & $\mathbf{0}$ & 83,931 & 39,275 \\
\hline Cumulative Cost & hare Contrib & ions & & & & 123,206 \\
\hline
\end{tabular}

\section{Appendix D.}

\section{Energy Savings Metrics}

\begin{tabular}{|c|c|}
\hline Method & $\begin{array}{c}\text { Energy per 1,000 } \mathrm{ft}^{2} \\
(\mathrm{kWh})\end{array}$ \\
\hline Autoclave & $1,150-4,000 \mathrm{kWh}$ \\
\hline $\begin{array}{c}\text { RF press } \\
\text { (30” x 40” platens) }\end{array}$ & $40-50 \mathrm{kWh}$ \\
\hline
\end{tabular}

\section{Projected RF energy savings of $>95 \%$}

Glass area, thickness, and materials will impact actual energy consumption for each process. The estimates made here are based upon laminating 2' x 3' panels from RF experiments and data gathered on autoclave processing. 